\author{
Przemysław Brona \\ Mgr inż. \\ Instytut Kolejnictwa \\ starszy specjalista inżynieryjnotechniczny \\ pbrona@ikolej.pl \\ Grzegorz Stencel \\ Mgr inż. \\ Instytut Kolejnictwa \\ starszy specjalista inżynieryjnotechniczny \\ gstencel@ikolej.pl
}

DOI: 10.35117/A_ENG_21_05_02

\title{
The issue of accessibility of passengers to trains from platforms, analyzed in the IN2STEMPO project, implemented as part of the Shift2Rail initiative
}

\begin{abstract}
The article presents the main objectives of the IN2STEMPO project, implemented under the Shift2Rail initiative, with particular emphasis on the issue of accessibility to trains from platforms. These are preliminary studies prepared under the IN2STEMPO project, which will end in September 2022. A short description of the Shift2Rail initiative itself is also provided..
\end{abstract}

Keywords: Accessibility; Railway infrastructure

\section{Introduction}

The project "Innovative solutions in the field of stations, energy, and power supply" IN2STEMPO, implemented as part of the Shift2Rail Joint Undertaking initiative of the Horizon 2020 program includes activities leading to the improvement of customer service quality and safety at stations, thus providing a better experience for passengers using the railways. In addition to basic information about the IN2STEMPO project, the article also presents one of the issues analyzed in the project, i.e. the accessibility of passengers to trains from the platforms.

\section{Shift2Rail Initiative}

Rail transport must meet the projected increase in customer demand for the services provided, as well as other challenges, including environmental, health, and technological challenges of the 21 st century $[5,6,9,12]$, as well as pursue the policy objectives of the European Union. The European research and innovation program for railways is currently Shift2Rail Joint Undertaking (Shift2Rail), which is a separate initiative established under the Horizon 2020 program, dedicated entirely to rail transport [14].

Shift2Rail is a public-private partnership launched for 2014-2024 to coordinate research activities and deliver innovation through a comprehensive approach focusing on the needs of the rail sector $[7,8,12]$. Shift2Rail as a research platform has the overarching goal of integrating research and innovation results in passenger rolling stock, freight, traffic management systems, and infrastructure from concept to market.

The primary purposes of designating Shift2Rail are as follows [15]:

- supporting the creation of a Single European Railway Area (SERA) leading to the achievement of smooth rail transport across Europe. This should be done by removing 
technical barriers that hinder the operation of the railway sector in terms of interoperability, ensuring proper interoperability of technical solutions,

- radically strengthening the competitiveness and attractiveness of the European rail industry, which is faced with the increasing competitiveness of US and Asian manufacturers,

- Maintaining and enhancing global market leadership in rail products and services through research and innovation activities that deliver competitive solutions and by stimulating and accelerating the market introduction of innovative solutions.

Shift2Rail's objectives are to be achieved by supporting research and innovation (R\&I) activities with funding from the public and private sectors. Partly financed by the Eighth Framework Program, Horizon 2020, by the European Union and partly by private funding.

Shift2Rail activities are set out in a common forward-looking strategic master plan and are structured around five key "innovation agendas" [11, 13, 14]:

- IP 1: Cost-effective and reliable trains, including high-speed, high-capacity trains;

- IP 2: Advanced traffic management and control systems;

- IP 3: Cost-effective and reliable infrastructure with high capacity;

- IP 4: IT solutions for attractive rail services;

- IP 5: Technologies for a sustainable and attractive European freight transport.

Each program identifies the challenges, objectives, and research activities to be pursued through research and innovation projects.

\section{IN2STEMPO project}

The IN2STEMPO project started on September 1, 2017, and will run until September 30, 2022. The project is coordinated by Network Rail. The consortium is made up of nineteen participants and eight related third parties (Figure 1). The Railway Institute is a related third party of PKP S.A. The total budget of the project is EUR 13.6 million, of which the maximum EU contribution is almost EUR 6 million.

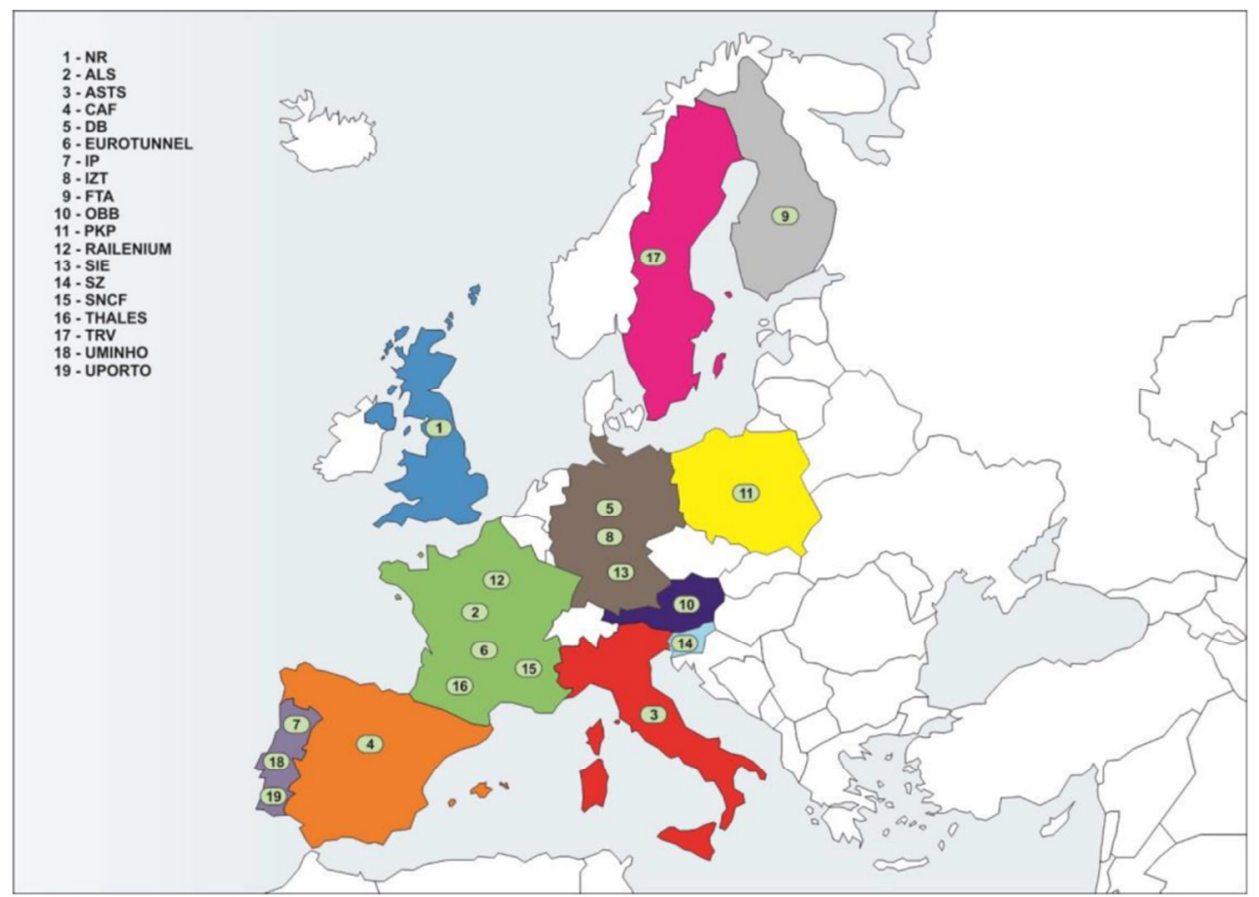

1. Partners in the IN2STEMPO project 
The Shift2Rail ambitions, which are realized by the IN2STEMPO project, require significant breakthrough improvements in the area of energy technology and in the area of stations. All activities within the individual tasks of the work package have been developed taking into account technical progress that goes beyond the current "state of the art".

Research carried out by the IN2STEMPO project contributes to the implementation of the three pillars of sustainable development, i.e.:

1. People (social impact);

2. Planet (impact on the environment);

3. Profit (impact on the economy);

strengthening and extending the benefits for local communities and the wider European society.

IN2STEMPO aims to develop criteria for smart, economical, and user-friendly stations with high capacity, taking into account functional aspects for all categories of passengers (elderly, blind, with reduced mobility), safety standards, solutions for multimodality and interoperability, reduction of energy consumption, passenger information systems and small stations and their importance for the European rail network. IN2STEMPO is divided into two sub-projects: energy and station (Fig. 2).

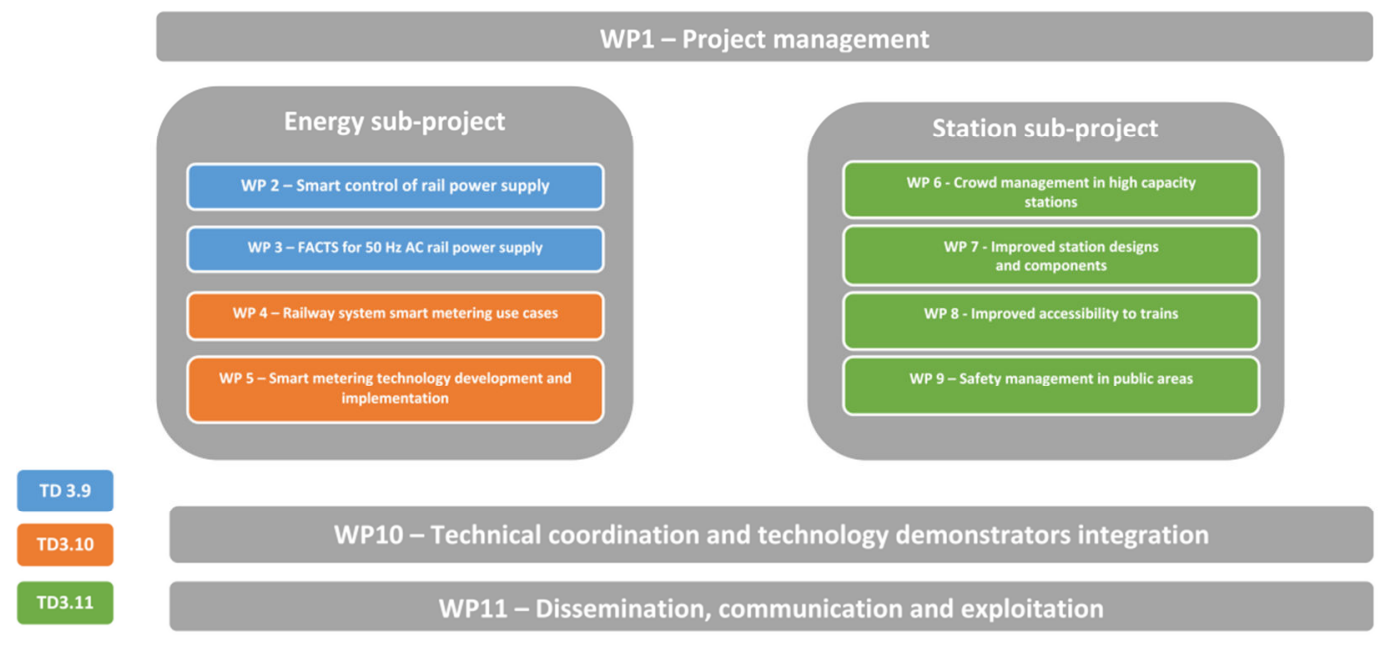

2. Work packages in the IN2STEMPO project

An intelligent power supply aims to combine energy resources into a single network, forming a system of connected vessels. Such a network will enable the integration of intelligent measurement data collection systems, innovative power electronic devices, energy management systems, and energy storage systems. This will improve operation, reduce electricity costs and increase the security of energy supply for the railway infrastructure. This system will be useful not only at the operation and maintenance stage but also at the investment stage.

Intelligent measurement systems consist in creating a network of intelligent measurement sensors in the railway system. As part of the system, it will be possible to collect and analyze data. The applications used in the system will allow for energy analysis, which will be used to improve the decision-making process regarding the energy consumed. As part of the system, it will be possible to create preventive maintenance plans, improve the asset management process, and manage life cycle costs.

The aim of the IN2STEMPO "station section" is to improve customer experience and safety at large stations during standard operations and in emergencies. Research focuses on improving passenger flow management at high-capacity stations, the design of stations and 
their components, train accessibility for all user groups and new ticketing technologies, leading to increased capacity, improved interoperability, and a better experience for rail passengers.

\section{Stations in the IN2STEMPO project}

The IN2STEMPO 'station section' is the challenge of developing a substation design method using cost-effective solutions and technologies that will have a positive impact on station management. A railway station is a showcase of rail transport, therefore an increase in the number of customers can be achieved by improving passenger service and station experiences.

" The station section "focuses on four work packages:

- crowd management at high capacity stations: a crowd management tool, especially in emergency situations, will be developed to ensure a smooth journey from start to finish as well as to support operational strategies (WP6),

- better station designs and components: designs of typical small stations will be developed to enable low energy consumption and the use of modern materials to meet passenger needs (WP7),

- Improving train accessibility - platform-train interface: proven methods will be developed to ensure safe crossing of the gap between the edge of the platform and the edge of the train floor (WP8),

- safety management in public areas: improving safety at the station and in public areas directly surrounding the station, including the development of specifications for resistant materials (including glass) - WP9.

The following partners participate in the WP6 $\div$ WP9 packages:

- NETWORK RAIL INFRASTRUCTURE LIMITED (NR),

- ANSALDO STS S.p.A. (ASTS),

- CAF TURNKEY \& ENGINEERING SOCIEDAD LIMITADA (CAF),

- INFRAESTRUTURAS DE PORTUGAL SA (IP),

- LIIKENNEVIRASTO (FTIA),

- ÖBB-Infrastruktur AG (ÖBB),

- POLSKIE KOLEJE PAŃSTWOWE SPÓŁKA AKCYJNA (PKP),

- SLOVENSKE ZELEZNICE DOO (SZ),

- THALES SERVICES SAS (THA);

as well as related third parties:

- Construcciones y auxiliar de Ferrocarriles Investigación y Desarrollo, S.L. (CAF I+D), associated with CAF,

- IP PATRIMONIO - ADMINISTRACAO E GESTAO IMOBILIARIA, SA (IP PATRIMONIO), associated with IP,

- HAMEEN AMMATTIKORKEAKOULU OY (HAMK), associated with FTIA,

- INSTYTUT KOLEJNICTWA (IK), associated with PKP,

- PROMENI INSTITUT LJUBLJANA DOO (PI), associated with SZ,

- SLOVENSKE ZELEZNICE-POTNISKI PROMETDRUZBA ZA OPRAVLJANJE PREVOZA POTNIKOV $\mathrm{V}$ NOTRANJEM IN MEDNARODNEM ZELEZNISKEM PROMETU DOO (SZ-PP), associated with SZ.

\section{Accessibility from platform to train}

Accessibility of rail transport for travelers is analyzed in all three work packages (WP6, WP7, WP8) related to the topic of stations in the IN2STEMPO project. In the WP8 work package, 
the subject of accessibility was addressed in particular in the context of the platform-train interface.

The main problem in passenger accessibility is the gap between the edge of the platform and the floor of the railway vehicle stopping at the platform. The definition of the gap is presented in the European Standard on railway gauges on railway networks in European countries PN-EN 15273-3 as a horizontal $\left(b_{\text {lac }}\right)$ and vertical $\left(h_{\text {lac }}\right)$ distance from the edge of the platform to the edge of the floor or access steps to the rolling stock. The basic dimensions defining the gap are shown in Figure 3.

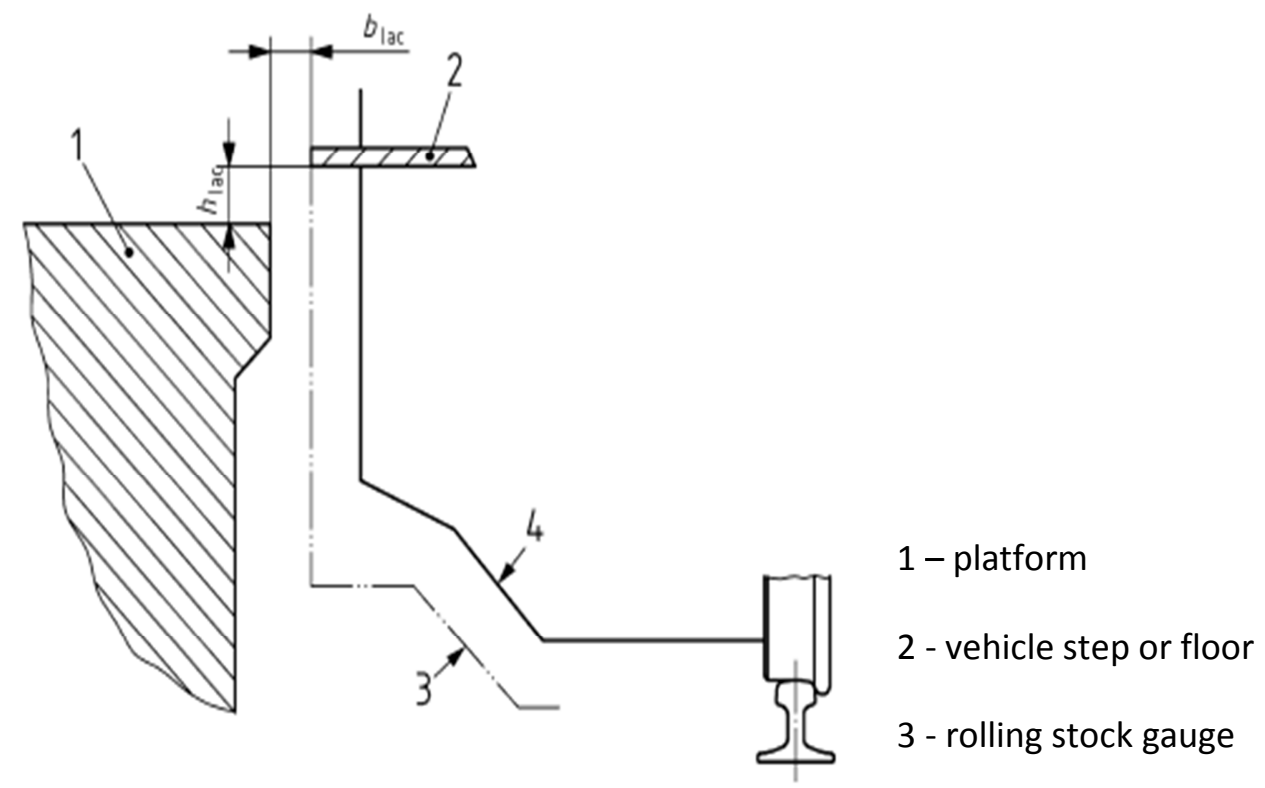

3. Basic dimensions defining the gap according to PN-EN 15273-3

For the technical aspects of accessibility from platforms to trains, the key issues are:

- height of the platforms. Despite the two standard platform heights specified in the Infrastructure TSI, i.e. 550 and $760 \mathrm{~mm}$ above the railhead, various platform heights are used in many European countries;

- track gauge with which the structure gauge and the rolling stock gauge are related, resulting in the use of rolling stock of different widths;

- types and types of rolling stock used. Rolling stock manufacturers and contracting authorities use different technical solutions to facilitate boarding and disembarking from the train;

- the possibility of using rolling stock running on a different track gauge for transport (e.g. running of standard-gauge rolling stock on the broad-gauge railway network).

Various technical aids are used to improve accessibility for travelers. These solutions are used both from the point of view of the railway infrastructure and the rolling stock. Individual solutions used on various railway networks and among carriers have been presented, among others in the article [2] and in a monograph [3].

As part of the In2Stempo project, technical solutions facilitating access from platforms to trains were identified in the partner countries. In most cases, they are related to the platform infrastructure and the transport rolling stock.

Technical solutions related to infrastructure include, first of all, solutions for the construction of platforms and devices located on the platform. These are, for example, the elevations of the platform parts to bring the platform height to the same level as the rolling 
stock floor, and all kinds of portable or permanent lifts and ramps that are folded out at the entrance doors to the carriages (Fig. 4).
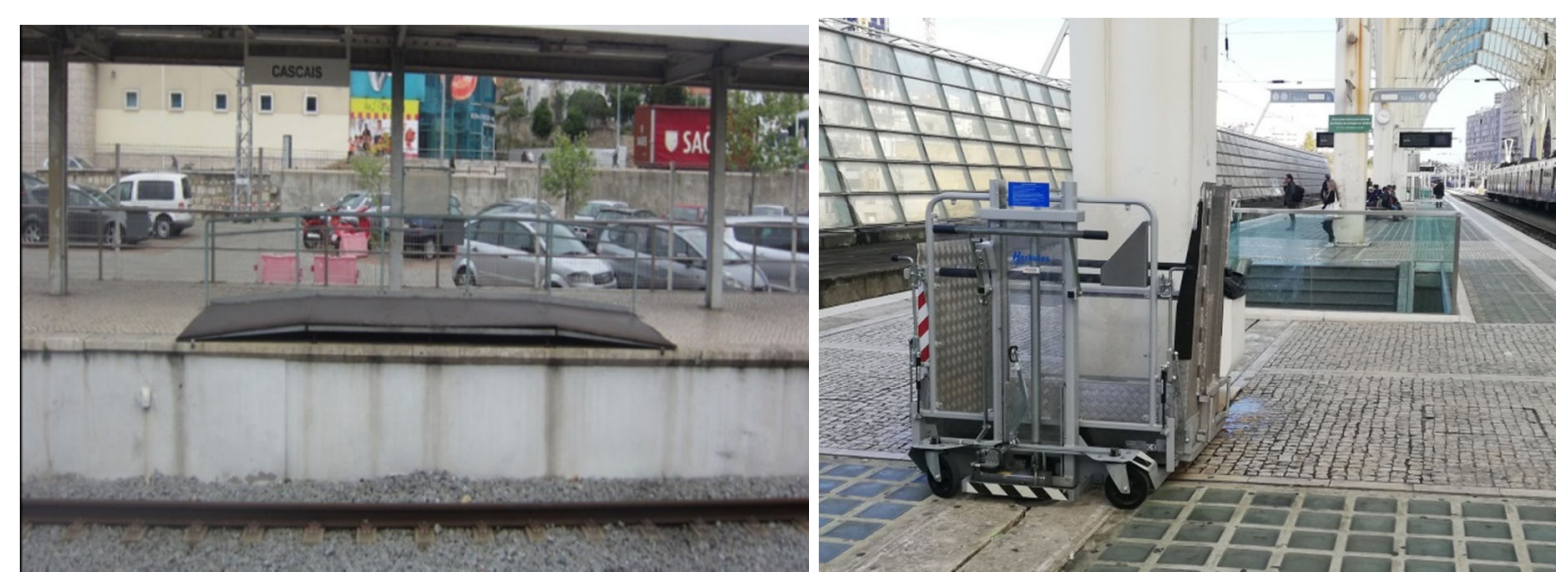

4. Raising part of the platform (a) and a portable platform lift (b)

In the case of solutions related to the transport fleet, the most common solutions include all kinds of lifts or elevators installed in the entrance doors to the carriages. Another type of boarding aids are folding ramps or floor elements (folded out by train crews), as well as steps that extend from the vehicle structure, which conceal the gap between the platform and the vehicle. Examples of such solutions are shown in Figure 5.
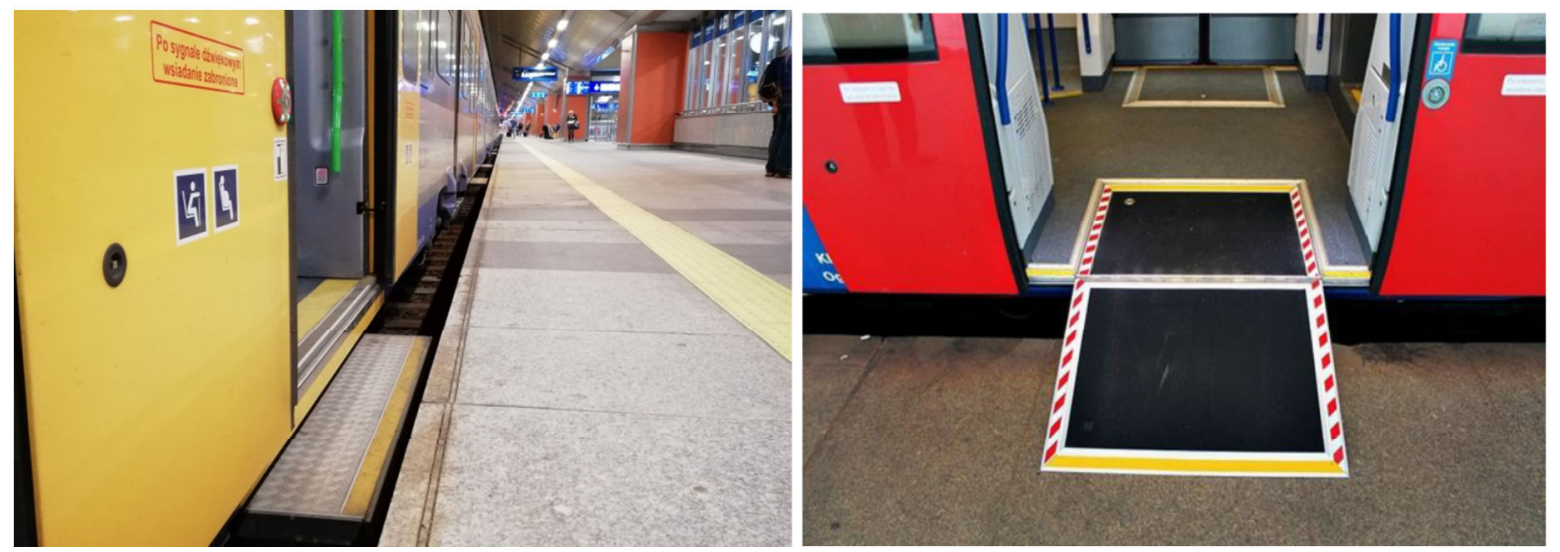

5. An extendable step covering the gap (a) and a folding ramp to the wagon (b)

The variety of solutions used is not always perceived positively by travelers. Some of these solutions cause problems with free access to trains (in particular for people in wheelchairs) and extend the time the train stops at a station or passenger stop.

In order to identify the needs and expectations of travelers, a survey was carried out among organizations representing disabled people in the countries of the partners participating in the project. The most important factors indicated by the respondents, which may have a positive impact on the improvement of accessibility to rail transport, were noted, inter alia, on: providing correct, up-to-date information about the lack or existence of facilities for disabled people, ensuring a safe route on the platform to the designated waiting place for the train, as well as the use of new solutions in the form of applications with information for travelers (current information about equipment failure, platform change, change train arrival and departure times, etc.).

On the basis of the identified problems and demands reported in the surveys by organizations representing disabled people, the partners participating in the IN2STEMPO 
project proposed three groups of solutions facilitating access to rail transport for all groups of travelers. These are:

- Platform related solutions;

- Solutions related to the transport fleet;

- Solutions in the field of new information and communication technologies (IT / ICT).

\section{Summary}

Railway stations in large agglomerations have become centers of commercial, service, and social activity. Therefore, there are problems related to congestion, lack of comfort for passengers, and the need to ensure safety in crisis situations. On the other hand, in the case of railway stations in small stations, the problem is to provide the space necessary to service travelers and space for commercial purposes, as well as the development of space around the station.

The aim of the IN2STEMPO project is to optimize the management of the stations by creating cost-effective solutions and technology development. It also aims to improve the customer experience at the stations and provide better services, which in turn is expected to lead to an increase in the number of rail customers.

Improving the offer of rail services requires focusing on the needs of customers, including passengers with reduced mobility. This goal can be achieved, inter alia, through the wide use of universal design, which will be positively felt not only by passengers with reduced mobility but also other groups of passengers $[1,3,4,5,10,11]$.

\section{Acknowledgments}

The IN2STEMPO project has received funding from Shift2Rail Joint Undertaking under the European Union's Horizon 2020 research and innovation programme under grant agreement No 777515.

Research work financed from the funds for science in 2018-2022 allocated to the implementation of an international co-financed project.
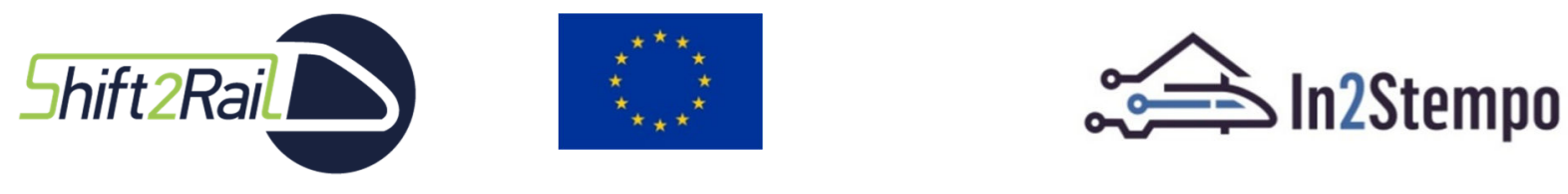

\section{Source materials}

[1] Fojud M., Fojud A.: Rola węzła multimodalnego $w$ ksztattowaniu zrównoważonej mobilności i jakości życia w mieście średniej wielkości - studium przypadku Nysy. Problemy Kolejnictwa, zeszyt nr 186, 2020, s. 29-42.

[2] Poliński J.: Luka między wagonem a peronem - rozwiąania poprawiające dostępność pociagu. Problemy Kolejnictwa, zeszyt nr 182, 2019, s. 55-69.

[3] Poliński J.: Rola peronów w dostępności transportu szynowego. Publikacja Instytutu Kolejnictwa. Oficyna Wydawnicza Politechniki Warszawskiej. Warszawa, 2019. ISBN: 978-83-8156-016-0.

[4] Poliński J., Ochociński K.: Metodyka opracowania strategii obstugi osób niepetnosprawnych na stacji pasażerskiej. Problemy Kolejnictwa, zeszyt nr 184, 2019, s. 39-47.

[5] Poliński J., Ochociński K.: Cyfryzacja w transporcie kolejowym. Problemy Kolejnictwa, zeszyt nr 188, 2020, s. 53-65. 
[6] Poliński J., Ochociński K.: Wpływ pandemii COVID-19 na funkcjonowanie pasażerskiego transportu kolejowego. Problemy Kolejnictwa, zeszyt nr 190, 2021, s. 31-43.

[7] Wawrzyn E.: Shift2Rail - inwestycje $w$ innowacje. Prace Naukowe Politechniki Warszawskiej, zeszyt 111, Warszawa, 2016, s. 585-597.

[8] Wawrzyn E., Stencel G.: Future Stations Solutions within IN2STEMPO Project of Shift2Rail. Proceedings of 24th International Scientific Conference. Transport Means 2020, p. 165-169. ISSN 1822-296 X (print) ISSN 2351-7034 (on-line).

[9] Wróbel I.: O projekcie In2Stempo na spotkaniu $w$ CUPT dotyczacym poprawy dostępności w transporcie. Prace Instytutu Kolejnictwa - Zeszyt 164 (2020).

[10] Wróbel I.: Poprawa dostepności transportu kolejowego dla osób z niepetnosprawnościami. Problemy Kolejnictwa, zeszyt nr 182, 2019, s. 181-191.

[11] Adopted Shift2Rail Multi Annual Action Plan dostępny na https://shift2rail.org/wpcontent/uploads/2013/07/S2R-JU-GB_Decision-N-15-2015-MAAP.pdf

[12] https://cordis.europa.eu

[13] Council Regulation (EU) No 642/2014 of 16 June 2014 establishing the Shift2Rail Joint Undertaking, OJ L 177.

[14] Shift2Rail Master Plan dostępny na https://ec.europa.eu/transport/sites/transport/files/modes/rail/doc/2015-03-31decisionn4-2015-adoption-s2r-masterplan.pdf

[15] WHITE PAPER Roadmap to a Single European Transport Area - Towards a competitive and resource efficient transport system, $\operatorname{COM(2011)~} 0144$ final 